\title{
ANALISIS SALURAN PEMASARAN KELAPA \\ (Suatu Kasus di Desa Karangkamiri Kecamatan Langkaplancar \\ Kabupaten Pangandaran)
}

\author{
ISEP ENDA NURHIDAYAT ${ }^{*}{ }^{*}$, DINI ROCHDIANI ${ }^{2}$, SUDRAJAT $^{1}$ \\ ${ }^{1}$ Fakultas Pertanian Universitas Galuh \\ ${ }^{2}$ Fakultas Pertanian Universitas Padjajaran \\ *Email : endaisep@gmail.com
}

\begin{abstract}
ABSTRAK
Hasil penelitian menunjukkan bahwa 1) hanya satu saluran pemasaran kelapa di Desa Karangkamiri Kecamatan Langkaplancar Kabupaten Pangandaran yaitu, Petani - Pedagang Pengumpul - Pedagang Besar - Konsumen Industri. 2) Marjin pemasaran kelapa di pedagang pengumpul 1.000,00 Rp/butir, biaya 475,00 Rp/butir dan keuntungan 525,00, Rp/butir sedangkan marjin pemasaran kelapa di pedagang besar 500,00 Rp/butir, biaya 200,00 Rp/butir dan keuntungan 300,00 Rp/butir. 3) Farmer's share adalah 62,50 persen dari harga yang dibayarkan konsumen.
\end{abstract}

Kata Kunci : Kelapa, Saluran Pemasaran

\section{PENDAHULUAN}

Menurut Sukamto (2008) kelapa adalah salah satu jenis tanaman perkebunan yang banyak ditanam oleh masyarakat pedesaan, mengingat tanaman kelapa memiliki peranan yang sangat besar bagi kehidupan masyarakat terutama dalam meningkatkan pendapatan. Selain itu kelapa mempunyai kemampuan berproduksi sepanjang tahun secara terus menerus dan siap jual kapanpun (dalam keadaan tua maupun muda) untuk memenuhi kebutuhan keluarga petani. Pengembangan usaha pengolahan produk kelapa melalui industrialisasi, selain meningkatkan produktivitas maupun kualitas produk juga akan memperbaiki nilai jual kelapa yang diterima oleh petani.

Dengan demikian banyak penggunaan kelapa sebagai bahan baku industri, sehingga motivasi petani untuk mengembangkan usahatani kelapa akan semakin meningkat.

Pemasaran buah kelapa tidak hanya ditujukan untuk kebutuhan bahan baku pabrik saja tetapi juga dijual dalam bentuk buah segar, selain itu juga digunakan sebagai bumbu masakan, Terdapat lembaga pemasaran yang menyalurkan barang-barang atau jasa dari produsen sampai konsumen, Maka konsumen tidak langsung mendapat buah kelapa dari produsen,

Saluran pemasaran yang efektif akan sangat dibutuhkan di Desa Karangkamiri, karena pencapaian tujuan yang sangat tepat dalam pemasaran merupakan bagian dari efisiensi pemasaran kelapa tersebut. Dengan adanya saluran pemasaran, diharapkan para petani dalam menjalankan usahatani kelapa tersebut 
mampu lebih berkembang dan lebih baik lagi.

\section{METODE PENELITIAN}

Metode survai adalah metode yg digunakan. Menurut Arikunto (2006) metode survei untuk mengetahui dan mengamati gejala empiris yang ada di lokasi penelitian. Mengenai unit sampel sebagai responden dan bukan seluruh populasi sasaran.

\section{Teknik Penarikan Sampel}

Penarikan sampel untuk petani dalam penelitian ini memakai metode simple random sampling. Dengan Responden sebanyak 30 orang petani yang diambil 10 persen dari total anggota populasi yaitu sebanyak 300 orang.

Sedangkan penarikan sampel untuk lembaga pemasaran dilakukan dengan Snowball Sampling Method.

\section{Rancangan Analisis Data}

Untuk mengetahui saluran pemasaran pada pemasaran kelapa dari petani sampai konsumen akhir dianalisis secara deskriptif kualittif. Sedangkan untuk mengetahui marjin, biaya, dan keuntungan pemasaran serta farmer's share dianalisis sebagai berikut :

1. Marjin pemasaran :

$$
\mathbf{M m}=\mathbf{P e}-\mathbf{P f}
$$

Terdapat 2 komponen yaitu biaya dan keuntungan, maka :

$$
\begin{array}{ll}
\mathrm{Mm} & =\pi+\mathrm{TC} \\
\pi & =\mathrm{Mm}-\mathrm{TC} \\
\mathrm{TC} & =\mathrm{Mm}-\pi
\end{array}
$$

2. Untuk menghitung biaya pemasaran digunakan rumus sebagai berikut :

$$
\mathbf{B}=\mathbf{M P}-\Pi
$$

3. Keuntungan :

$$
\pi=\mathbf{M m}-\mathrm{TC}
$$

4. Untuk mengetahui bagian harga yang diterima petani (farmer's share) menggunakan rumus (Angipora, 2002) :

$$
\mathbf{F}=\frac{P f}{P r} \times 100 \%
$$

\section{Tempat dan Waktu Penelitian}

Desa Karangkamiri Kecamatan Langkaplancar Kabupaten Pangandaran adalah tempat penelitian. Adapun waktu penelitian dibagi dalam tahapan sebagai berikut :

1) Tahapan persiapan yaitu survei pendahuluan, penulisan Usulan Penelitian, dan Seminar Usulan Penelitian dilaksanakan pada bulan April sampai dengan Mei 2019.

2) Tahapan pengumpulan data dari lapangan, yaitu pengumpulan data dilaksanakan pada bulan Juni sampai 2019. 
3) Tahapan pengolahan dan analisis data, penyusunan serta penulisan skripsi dilaksanakan pada bulan Juli 2019 sampai selesai

\section{HASIL DAN PEMBAHASAN}

Berdasarkan hasil penelitian di hanya satu saluran pemasaran kelapa sebagai berikut : Petani - Pedagang Pengumpul Desa Karangkamiri - Pedagang Besar Pasar Cirebon- Konsumen Industri

Tabel 1. Rata-rata Biaya, Marjin Pemasaran, dan Farmer's Share Pemasaran Kelapa.

\begin{tabular}{clrc}
\hline No. & \multicolumn{1}{c}{ Lembaga Pemasaran } & Satuan (Rp/Butir) & Fs $(\%)$ \\
\hline 1. & Petani & & 62,50 \\
& Harga Jual & $2.500,00$ & \\
2. & Pedagang Pengumpul & $2.500,00$ \\
& Harga Beli & $3.500,00$ \\
& Harga Jual & $1.000,00$ \\
Marjin & 475,00 \\
Biaya & 525,00 \\
Keuntungan & \\
Pedagang Besar & $3.500,00$ \\
Harga Beli & $4.000,00$ \\
Harga Jual & 500,00 \\
Marjin & 200,00 \\
Biaya & 300,00 \\
Keuntungan & \\
Jumlah & 675,00 \\
Biaya & 825,00 \\
Keuntungan & $1.500,00$ \\
Marjin & \\
\hline
\end{tabular}

\section{Farmer's Share}

Farmer's Share adalah persentase harga yang diterima petani dari harga yang dibayarkan oleh konsumen. Untung ruginya petani tidak ditentukan oleh besar kecilnya nilai farmer's share, tetapi dipengaruhi oleh harga produk dan biaya yang dikeluarkan.

$$
F s i=\frac{H p}{H e} \times 100 \%
$$

$$
\text { Fsi }=\frac{2.500}{4.000} \times 100 \%
$$

$\mathrm{Fsi}=62,50 \%$

Dari hasil perhitungan diperoleh nilai farmer's share adalah sebesar 62,50 persen, artinya harga yang diterima petani adalah sebesar 62,50 persen dari harga yang dibayarkan oleh konsumen. 


\section{KESIMPULAN DAN SARAN}

\section{Kesimpulan}

Berdasarkan hasil penelitian dan pembahasan maka dapat disimpulkan sebagai berikut :

1) Di Desa Karangkamiri Kecamatan Langkaplancar Kabupaten Pangandaran terdapat satu saluran pemasaran yaitu :

2) Petani - Pedagang Pengumpul Desa Karangkamiri - Pedagang Besar Cirebon - Konsumen Industri.

3) Marjin pemasaran kelapa di pedagang pengumpul $1.000,00$ Rp/butir, biaya 475,00 Rp/butir dan keuntungan 525,00, Rp/butir, sedangkan marjin pemasaran kelapa di pedagang besar 500,00 $\mathrm{Rp} /$ butir, biaya 200,00 Rp/butir dan keuntungan 300,00 Rp/butir.
4) Farmer's share atau bagian harga yang diterima petani adalah 62,50 persen dari harga yang dibayarkan konsumen.

\section{Saran}

Untuk menjaga harga ditingkat petani tetap stabil,disarankan kepada petani untuk menjaga kualitas produksi agar dapat bersaing dipasaran, dan untuk lembaga pemasaran disarankan untuk mengefesiensikan biaya pemasaran yaitu dengan efesiensi biaya transfortasi agar mampu menghasilkan keuntungan yang optimal.

\section{DAFTAR PUSTAKA}

Arikunto, S. 2006. Prosedur Penelitian Suatu Pendekatan Praktek. Rineka Cipta. Jakarta.

Sukamto. 2008. Upaya meningkatkan Produksi Kelapa. Penerbit PT. Penebar Swadaya. Jakarta. 